\title{
KEUDUDUKAN HUKUM PARA PIHAK DALAM SENGKETA TANAH DAN BANGUNAN BENTENG PENDEM NGAWI-EX KNIL BELANDA
}

\author{
Karyoto $^{1}$, Nurbaedah ${ }^{2}$, Sholahuddin. ${ }^{3}$ \\ Program Pasca Sarjana Fakultas Hukum Universitas Islam Kadiri \\ Jl. Sersan Suharmaji Nomor. 38, Manisrenggo, Kota Kediri, Kediri, \\ Jawa Timur 64128, Indonesia. \\ Email : yotoahmad @ gmail.com
}

\begin{abstract}
The background of this study is the dispute over land and building of Benteng Pendem Ngawi in Ngawi Regency which are claimed by several different parties including TNI $A D$ Kodam V Brawihaya Cq Batalyon Armed Nhawi, the Local Government of Ngawi Regency, and the Ministry of Law and Human Rights, Cq Correctional Instritution of Ngawi Regency. This study aims to clarify the legal standing of the three parties in the dispute of over Benteng Pendem Ngawi -which was a former of the Dutch's KNIL. The method adopted in this study is called legal research (normative) with case approach, in this context the dispute has become the object of the study. The legal materials for this study consists of primary legal materials such as Government Regulation (PP NO 24 tahun 1997) on Land Registration, the Civil Law (KUHPer/BW) and Minister of Agraririan/Head of Land Authority Regulation No 3 Year 1997. The secondary legal materials draw on Official documents including academic papers, textbooks, Journals in Law Field, commentary on court's verdict, and other materials not directly related to the field of Law which is used to clarify and guide in understanding both the primary and the secondary legal materials i.e. KBBI (the Dictionary of Bahasa Indonesia). The results of the study show that the legal standing of TNI AD KODAM v/Brawijaya Cq Batalyon Armed Ngawi over the ownership of the land and building of Benteng Pendem is legal based on the occupational rights obtained over Military Emergency condition. While the legal standing of Ngawi Regency Local Government, although administratively does not own the documents stating the data of Benteng Pendem, still holds the rights to conserve the heritage site. Relating to the legal standing of Correctional Instritution of Ngawi Regency (LP Ngawi), historical documents produced in the Collonial era stated that the ownership of the land was taken over from Dep V. Oerlog to Dep V. Justitie and since then the land has been owned by LP Ngawi. This is supported by the documents of land and building of Benteng Pendem Ngawi.
\end{abstract}

Keywords : Legal status, Land and building disputes, Benteng Pendem Ngawi

\begin{abstract}
ABSTRAK
Penelitian ini dilatarbelakangi sengketa tanah dan bangunan Benteng Pendem Ngawi di Kabupaten Ngawi yang sekarang menjadi polemik beberapa pihak yang mengklaim lebih layak untuk mengusai tanah tersebut, yaitu TNI AD Kodam V/Brawijaya Cq Batalyon Armed Ngawi, Pemerintah Daerah Kabupaten Ngawi dan Kementerian Hukum dan HAM, Cq Lembaga Pemasyarakatan Kabupaten Ngawi. Rumusan masalah penelitian ini
\end{abstract}

${ }^{1}$ Submission : $15-12-2018$ | Review - 1: $1-3-2019$ | Review - 2: $1-3-2019$ | Production : $2-3-2019$ 
adalah bagaimana keududukan hukum para pihak dalam sengketa tanah dan bangunan Benteng Pendem Ngawi-Ex Knil Belanda di Kabupaten Ngawi. Penelitian ini menggunakan metode legal research (normatif) dengan pendekatan kasus, yang dalam hal ini menjadikan kasus sengketa tanah dan bangunan benteng Pendem Ngawi di Kabupaten Ngawi sebagai objek dasar kajian penelitian. Bahan hukum penelitian ini terdiri dari bahan hukum primer yang dalam hal seperti Peraturan Pemerintah Nomor 24 Tahun 1997 tentang Pendaftaran Tanah, Kitab Undang-Undang Hukum Perdata (KUHPer/BW) serta Peraturan Menteri Agraria/Kepala Badan Pertananahan Nasional Nomor 3 Tahun 1997. Kemudian bahan skunder terdiri dari dokumen-dokumen resmi, meliputi karya tulis, buku-buku teks, jurnal-jurnal hukum dan komentar-komentar atas putusan pengadilan, serta terakhir adalah bahan non-hukum, yaitu bahan yang memberikan penjelasan maupun petunjuk terhadap bahan hukum primer maupun sekunder yang telah ada seperti Kamus Besar Bahasa Indonesia. Hasil penelitian menunjukkan bahwa kedudukan hukum TNI AD KODAM V/Brawijaya Cq Batalyon Armed Ngawi dalam penguasaan tanah dan bangunan banteng adalah sah hal tersebut didasarkan pada hak okupasi tanah dan bangunan Benteng Pendem Ngawi yang diperoleh pada saat Negara dalam Keadaan Darurat Militer. Kemudian untuk kedudukan hukum Pemerintah Daerah Kabupaten Ngawi, secara Administrasi memang tidak memiliki dokumen data tanah dan Bangunan Benteng Pendem Ngawi, namun demikian Pemerintah Daerah Kabupaten Ngawi berwenang untuk melestarikan Peninggalan sejarah Purbakala sebagai Budaya bangsa yang harus diamankan dan dijunjung tinggi. Terkait kedudukan Lembaga Pemasyarakatan Ngawi (LP Ngawi) dalam penguasaan tanah tersebut bahwa menurut catatan yang ada sejak jaman Kolonial Belanda oleh Dep.V.Oerlog telah diserahkan kepada Dep. V. Justitie dan sejak itu telah berpuluh puluh tahun lamanya dikuasai dan diawasi oleh LP. Ngawi dan hal tersebut diperkuat dengan dokumen data tanah dan bangunan Benteng Pendem Ngawi.

Kata kunci : Keududukan hukum, Sengkata tanah dan bangunan, Benteng Pendem Ngawi 


\section{Pendahuluan}

Tanah yang diatasnya berdiri bangunan, memiliki arti yang sangat penting bagi Negara dan bagi setiap orang, baik dalam kedudukanya sebagai individu maupun sebagai anggota masyarakat, sejak lahir, hidup, bahkan sampai meninggal duniapun tanah dan bangunan tidak dapat dilepaskan dari kehidupan manusia atau kelangsungan berdirinya suatu Negara.

Tanah merupakan faktor pendukung utama dalam penyelenggaraan kehidupan berbangsa dan bernegara untuk kesejahteraan rakyatnya. Kebutuhan akan tanah tidak hanya terbatas untuk kebutuhan tempat tinggal rakyatnya, untuk berteduh dan lain-lain, tetapi tanah juga tempat tumbuh kembangnya masyarakat dalam lingkungan sosial bernegara, berpolitik, ekonomi dan budaya bagi, masyarakat untuk berkomunitas dalam berbangsa dan bernegara.

Arti pentingnya tanah bagi kehidupan masyarakat dalam suatu Negara, ini didasarkan oleh kenyataan, bahwa tanah memiliki arti yang strategis bagi kehidupan masyarakat dalam suatu bangsa dan Negara, mengingat kebutuhan akan tanah yang terus meningkat, sedangkan pada sisi lain ketersediaan tanah semakin terbatas, untuk tempat kehidupan masyarakat dalam Negara.

Menurut Michael G. Kitay menyatakan: "land is unique and limited; it is therefore valuable. And whoever controls and the land controls a potential profitable asset". 2 Pendapat senada juga dikemukakan oleh Lawson dan Rudden, mengatakan "Land is unique it is permanent, almost indestructible, has income value and is capable of almost infinite division and sub division". 3

Sehubungan dengan arti pentingnya tanah bagi kehidupan masyarakat, berbangsa dan bernegara, sehingga terkadang tanah sering menjadi objek sengketa, baik tanah perseorangan atau tanah negara yang dikuasai oleh pemerintah antar Instansi Pemerintah itu sendiri, maupun tanah milik negara yang dikuasai masyarakat untuk tempat tinggal rakyatnya.

\footnotetext{
${ }^{2}$ Michael G. Kitay, Land Acquistion in Deeveloping Countries, Policies and Procedures of the Public Sector (A Linclon Institute of Land Policy Book, 1983). Hlm. 2

${ }^{3}$ Dianne Chappellle, Land Law (London: Pitman Publishing, 1997). Hlm. 6
} 
Sengketa tanah pada umumnya menyangkut penguasaan, pendudukan, pengelolaan, pemeliharaan, kemanfaatan, kepemilikan dan semua itu membutuhkan perlindungan hukum, untuk menyelesaikan sengketa atas tanah.

Pada umumnya dalam hukum tanah itu sendiri juga terjadinya persoalan hukum, hal ini disebabkan tidak adanya landasan hukum yang jelas yang mendasari hak penguasaan, perolehan, dan pengelolaan hak atas tanah, terutama tanah-tanah bekas hak-hak barat, termasuk tanah Peninggalan Ex Knil Belanda, seperti tanah bekas peningggalan Tentara Belanda, markasmarkas/kompi-kompi, Benteng-benteng Pertahanan Tentara kolonial Belanda, pada saat menjajah di Indonesia.

Mengenai terjadinya sengketa tanah Peninggalan Ex Knil Belanda ini rata-rata, disebabkan oleh beberapa faktor, baik yang berkaitan dengan faktor hukum, ekonomi, sosial, politik maupun faktor lain di luar faktor hukum.

Diwilayah Pemerintah Daerah Kabupaten Ngawi, terdapat tanah dan bangunan bekas peninggalan Tentara Knil Belanda, pada saat Belanda menjajah di Indonesia, dikenal dengan nama, Benteng Pendem Ngawi, terletak di Kelurahan Pelem Kecamatan Ngawi Kabupaten Ngawi Propinsi Jawa Timur. Pada saat penelitian ini dibuat, lokasi tanah dan bangunan Benteng Pendem Ngawi, berubah status, yang terdahulu untuk Asrama dan Gudang Munisi serta untuk Latihan Militer Batalyon Armed Ngawi, menjadi lokasi Pariwisata, yang dikelola oleh Pemerintah Daerah Kabupaten Ngawi bersama dengan TNI AD Kodam V/Brawijaya Cq Batalyon Armed Ngawi, namun secara administrasi belum diadakan bentuk perjanjian kerjasama Pemanfaatan Aset Negara antara TNI AD Kodam V/Brawijaya Cq Batalyon Armed Ngawi dengan Pemerintah Daerah Kabupaten Ngawi.

Pada mulanya Penguasaan dan pendudukan TNI AD Kodam V/Brawijaya Cq Batalyon Armed Ngawi terhadap tanah dan bangunan Benteng Pendem Ngawi sejak tahun 1945, diperoleh dari peninggalan Tentara Ex Knil Belanda, dan pada tahun 1950 oleh Zidam V/Brawijaya, dilakukan Pemetaan dan Penggambaran Denah Lokasi bidang tanah dan bangunan Benteng Pendem Ngawi, bersama- sama dengan Kepala Kantor Pendaftaran 
Tanah (KKP) setempat Ngawi, sekarang dikenal dengan nama kantor BPN/ATN Kabupaten Ngawi.

Penguasaan TNI AD terhadap tanah dan bangunan dilakukan pada saat Negara dalam keadaan darurat, disebut dengan nama Okupasi TNI AD diperkuat dengan Perpu No. 23 tahun 1959 tentang Pencabuatan Undang Undang Nomor 74 Tahun 1957 dan menetapkan Keadaan Bahaya.

Permasalahan yang terjadi adalah, tanah dan bangunan Benteng Pendem Ngawi, ada tiga Pengakuan Penguasaan yaitu : Pertama, TNI AD Kodam V/Brawijaya Cq Batalyon Armed Ngawi, mengaku bahwa tanah dan bangunan Benteng Pendem Ngawi, adalah aset Negara dalam pengelolaan TNI AD Kodam V/Brawijaya, karena yang mengokupasi awal adalah TNI AD Kodam V/Brawijaya Cq Batalyon Armed Ngawi, atas dasar Darurat Militer, digunakan untuk Asrama Prajurit, Gudang Munisi dan Latihan Militer Batalyon Armed Ngawi.

Kedua, Pemerintah Daerah Kabupaten Ngawi, mengakui bahwa tanah dan bangunan Benteng Pendem Ngawi, adalah Aset Pemerintah Daerah Ngawi, karena dalam Wilayah Pemerintah Daerah Kabupaten Ngawi, dan merupakan peninggalan Purbakala, maka dapat digunakan untuk Pariwisata.

Ketiga, Kementerian Hukum dan HAM, Cq Lembaga Pemasyarakatan Kabupaten Ngawi (LP Ngawi), mengaku tanah dan bangunan Benteng Pendem Ngawi adalah Aset Kementerian Hukum dan HAM melalui LP Ngawi, dengan alasan, sejak tahun 1965 sampai dengan tahun sekarang LP. Ngawi, menguasai tanah, untuk Pertanian, digunakan untuk pendidikan/pelatihan bertani dan bertenak bagi Nara Pidana yang akan keluar/dilepas menjadi masyarakat umum. Permasalahan penguasaan tanah dan bangunan Benteng Pendem Ngawi tersebut, disebabkan karena Instansi Pemerintah melalui Kementerian masing-masing mengeluarkan Peraturan tentang tanah dan bangunan bekas peninggalan hak-hak barat, sedangkan UUPA No 5 tahun 1960 kurang tegas dalam menjelaskan, menjabarkan makna dan substansi tanah bekas hak hak barat, termasuk tanah Benteng Pendem Ngawi Ex Knil Belanda. 
Penelitian yang membahas tentang penyelesaian hukum sengketa tanah dan bangunan sudah cukup banyak dilakukan oleh para peneliti terdahulu. Berdasarkan hasil penelusuran terhadap beberapa literatur yang telah dilakukan, maka setidaknya ditemukan beberapa literatur yang membahas mengenai permasalahan ini.

Pertama, Dias Restu Wijayanti dengan judul Upaya Penyelesaian Sengketa Tanah Antara Masyarakat dengan TNI (Studi Kasus di Desa Setrojenar, Kecamatan Buluspesantren, Kabupaten Kebumen) Tahun 2015 yang dalam penelitiannya tersebut membahas tentang penyebab terjadinya sengketa tanah antara masyarakat dengan TNI di Desa Setrojenar, Kecamatan Buluspesantren, Kabupaten Kebumen serta upaya penyelesaian sengketa tanah antara masyarakat dengan TNI di Desa Setrojenar, Kecamatan Buluspesantren, Kabupaten Kebumen tahun 2015. ${ }^{4}$

Hasil penelitian tersebut menunjukkan bahwa penyebab dari adanya masalah tersebut karena adanya perbedaan persepsi kawasan pertahanan dan uji coba senjata dalam penggunaan wilayah pantai oleh TNI, sedangkan petani dalam penggunaan kawasan tersebut dapat ditanami sampai PAL Budeg. Kedua belah pihak saling mengklaim tanah yang ada disana. Kemudian hasil temuan lainnya menunjukkan bahwa sampai saat ini karena kedua belah pihak tidak dapat menyelesaikannya sendiri, maka Pemerintah Kabupaten Kebumen mengupayakan penyelesaian sengketa tanah dengan membentuk tim independen atau tim mediasi dengan melibatkan praktisi hukum dan ahli pertanahan yang dibentuk pada tanggal 14 September 2015. Tim ini terdiri dari 7 orang, yang berasal dari UGM, Sekolah Tinggi Pertanahan, BPN Pusat dan BPN Kabupaten Kebumen. Tim ahli ini, bukan merupakan lembaga Arbitrase yang bisa mengambil keputusan bersifat final dan mengikat, yakni keberadaan tim mediasi ini tidak punya kewenangan untuk memutuskan pihak mana yang memiliki hak atas tanah sengketa tersebut. Tim ahli ini hanya memetakan permasalahan yang muncul mengenai klaim itu benar atau tidak

${ }^{4}$ Dias Restu Wijayanti, Upaya Penyelesaian Sengketa Tanah Antara Masyarakat Dengan TNI (Studi Kasus Di Desa Setrojenar, Kecamatan Buluspesantren, Kabupaten Kebumen) Tahun 2015 (FKIP, Universitas PGRI Yogyakarta, n.d.). hlm. 3 
dan mengambil kesimpulan verifikasi bukti surat. Jadi tim mediasi ini menyuruh kedua belah pihak baik dari masyarakat maupun TNI untuk segera mengumpulkan bukti-bukti otentik berupa surat yang dimiliki. Selanjutnya akan diproses melalui tim mediasi tersebut. ${ }^{5}$

Kedua, Shidarta dengan judul Peragaan Pola Penalaran Hukum dalam Kajian Putusan Kasus Tanah Adat Kajian Putusan Nomor 22/PDT.G/2004/PN.AB pada tahun 2010 yang dalam penelitiannya tersebut membahas tentang bagaimana hakim menampilkan pola-pola penalarannya dalam putusan Pengadilan Negeri Ambon bernomor perkara 22/Pdt.G/2004/PN.AB. ${ }^{6}$

Hasil penelitian tersebut menunjukkan bahwa peragaan penalaran hukum dapat ditampilkan secara sederhana melalui perumusan silogismesilogismeposisi premis mayor dalam suatu silogisme menjadi indikator paling fundamental terkait kualitas putusan tersebut, termasuk untuk mencermati ada tidaknya penemuan hukum baru dari putusan tersebut (3) putusan hakim yang bersinggungan dengan kasus-kasus hukum adat, termasuk hukum tanah adat, kerap dipengaruhi oleh konfgurasi politik hukum yang menempatkan posisi hukum negara di atas hukum adat; dan (4) kondisi pluralisme hukum yang lemah akan memberi keuntungan pada pihak-pihak yang mampu menampilkan bukti-bukti formal semata menurut perspektif hukum negara. Terkait dengan putusan Pengadilan Negeri Ambon nomor 22/Pdt.G/2004/PN.AB ini, majelis hakim telah memperagakan pola-pola penalaran yang melalui analisis terhadap premis-permis mayornya, ternyata bertumpu sepenuhnya pada pendekatan formalisme hukum. Dalam konteks ini, karakteristik kasus ini sebagai sengketa tanah adat menjadi hilang dan berganti menjadi sengketa yang sepenuhnya bernuansa hukum negara. Hal ini menguatkan fenomena tentang pluralisme hukum lemah dalam tradisi sistem

\footnotetext{
${ }^{5}$ Dias Restu Wijayanti. Hlm. 14

${ }^{6}$ Shidarta, "Peragaan Pola Penalaran Hukum Dalam Kajian Putusan Kasus Tanah Adat Kajian Putusan Nomor 22/PDT.G/2004/PN.AB," JURNAL YUDISIAL 3, no. 3 (2010). Hlm. 211
} 
hukum Indonesia, sekalipun dalam ranah hukum agraria yang konon menurut UUPA, telah dibangun berdasarkan sendi-sendi hukum adat. ${ }^{7}$

\section{Rumusan Masalah}

Berdasarkan penjelasan di atas, maka dapat diketahui yang menjadi rumusan masalah dalam penelitian ini adalah bagaimana kedudukan hukum para pihak dalam sengketa tanah dan bangunan Benteng Pendem Ngawi-Ex Knil Belanda di Kabupaten Ngawi.

\section{Tujuan Penelitian}

Tujuan penelitian ini adalah untuk mengkaji secara mendalam keududukan hukum para pihak dalam sengketa tanah dan bangunan Benteng Pendem Ngawi-Ex Knil Belanda di Kabupaten Ngawi.

\section{Metode Penelitian}

Penelitian ini menggunakan metode legal research (normatif) dengan pendekatan perundang-undangan dan kasus yang dalam hal ini menjadikan kasus sengketa tanah dan bangunan benteng Pendem Ngawi di Kabupaten Ngawi sebagai dasar kajian penelitian. Bahan hukum penelitian ini terdiri dari bahan hukum primer yang dalam hal seperti Peraturan Pemerintah Noomor 24 Tahun 1997 tentang Pendaftaran Tanah, Kitab Undang-Undang Hukum Perdata (KUHPer/BW) serta Peraturan Menteri Agraria/Kepala Badan Pertananahan Nasional Nomor 3 Tahun 1997. Kemudian bahan skunder terdiri dari dokumen-dokumen resmi, meliputi karya tulis, buku-buku teks, jurnaljurnal hukum dan komentar-komentar atas putusan pengadilan, serta terakhir adalah bahan non-hukum, yaitu bahan yang memberikan penjelasan maupun petunjuk terhadap bahan hukum primer maupun sekunder yang telah ada seperti Kamus Besar Bahasa Indonesia dan lain sebagainya yang digunakan untuk mencari istilah-istilah dalam rangka menjelaskan hal-hal yang digunakan dalam bahan hukum primer maupun bahan hukum sekunder.

\footnotetext{
${ }^{7}$ Shidarta. Hlm. 218
} 
Teknik Pengumpulan data yang akan digunakan dalam penelitian hukum ini yaitu inventarisasi norma hukum, identifikasi serta wawancara. Inventarisasi, yaitu dengan mencari dan mengumpulakan dokumen-dokumen dan bahan-bahan pustaka, kemudian diseleksi yang sesuai dengan tema pembahasan dalam penelitian ini sedangkan identifikasi data dan norma, yaitu menetapkan kriteria identifikasi untuk menyeleksi norma-norma yang termasuk hukum positif atau norma sosial yang bukan norma hukum. Adapun teknik pengumpulan data kualitatif dilakukan melalui melalui wawancara yang mendalam dengan petugas atau pejabat yang memiliki kaitan dengan objek permasalahan dalam penelitian ini.

Metode yang digunakan untuk menganalisis dan mengolah data-data yang terkumpul adalah metode deskriptif kualitatif. Maksud dari penggunaan metode tersebut adalah memberikan gambaran terhadap pemasalahan berdasarkan pada pendekatan yuridis normatif. ${ }^{8}$

\section{Hasil Penelitian dan Pembahasan}

\subsection{Pendaftaran Hak Atas Tanah}

Menurut Peraturan Pemerintah Nomor 24 Tahun 1997 sebagai penyempurnaan dari Peraturan Pemerintah Nomor 10 Tahun 1961 tentang Pendaftaran Tanah, menetapkan bahwa untuk memberikan kepastian dan perlindungan hukum kepada pemegang hak yang bersangkutan diberikan sertipikat hak atas tanah. ${ }^{9}$ Sertipikat hak atas tanah diberikan sesuai dengan data fisik dan data yuridis yang telah terdaftar dalam buku tanah. ${ }^{10}$

Terdaftarnya dalam buku tanah atas hak atas tanah dilakukan setelah data fisik maupun data yuridis tersebut melalui tahapan-tahapan pembuktian dengan meneliti kebenaran alat bukti yang dilakukan oleh

\footnotetext{
${ }^{8}$ Ade Saptomo, Pokok-Pokok Metodologi Penelitian Hukum (Surabaya: Unesa University Press, 2007). Hlm. 30

${ }^{9}$ Pasal 3 dan 4 ayat (1) Peraturan Pemerintah Nomor 24 Tahun 1997 tentang Pendaftaran Tanah.

${ }^{10}$ Pasal 30 dan Pasal 31 Peraturan Pemerintah Nomor 24 Tahun 1997, tentang Pendaftaran Tanah
} 
Panitia ajudikasi dalam pendaftaran tanah secara sistematik, atau oleh Kepala Kantor Pertanahan dalam pendaftaran tanah secara sporadik. ${ }^{11}$

Pendaftaran tanah menurut Peraturan Pemerintah Nomor 10 Tahun 1961 jo Peraturan Pemerintah Nomor 24 Tahun 1997, adalah penyelenggaraan pendaftaran tanah secara sistematik maupun sporadik, merupakan pendaftaran tanah yang meliputi kadaster dan pendaftaran hak, walaupun tidak dijelaskan dalam Peraturan Pemerintah tersebut.

Berdasarkan Peraturan Pemerintah Nomor 24 Tahun 1997 terkait dengan pembukuan hak atas tanah dalam buku-tanah (daftar umum) dilakukan setelah bidang-bidang tanah yang menjadi objek hak-hak itu diukur dan dipetakan pada peta-peta pendaftaran. ${ }^{12}$ Kepada pemegang hak yang haknya telah didaftarkan dalam buku-tanah diberikan sertipikat sebagai surat tanda bukti hak. ${ }^{13}$

Dalam rangka penyajian data fisik dan data yuridis, Kantor Pertanahan menyelenggarakan tata usaha pendaftaran tanah dalam daftar umum. Daftar-umum terdiri dari, peta pendaftaran, daftar tanah, surat ukur, buku tanah dan daftar nama. ${ }^{14}$ Berdasarkan ketentuan-ketentuan tersebut di atas dapat ditarik kesimpulan, bahwa buku tanah yang diadakan dalam rangka pendaftaran hak atas tanah yang dari padanya diterbitkan sertipikat merupakan daftar umum yang mempunyai kekuatan hukum, yang dimaksud dengan pendaftaran tanah oleh pemerintah menurut Peraturan Pemerintah Nomor 24 Tahun 1997 adalah pendaftaran tanah yang meliputi pendaftaran hak.

\footnotetext{
${ }^{11}$ Pasal 25 Peraturan Pemerintah Nomor 24 Tahun 1997, tentang Pendaftaran Tanah

${ }^{12}$ Pasal 23-30 Peraturan Pemerintah Nomor 24 Tahun 1997, tentang Pendaftaran Tanah
}

${ }^{13}$ Sertipikat adalah surat tanda- bukti-hak yang berlaku sebagai alat pembuktian yang kuat mengenai data fisik dan data yuridis atas tanah yang termuat di dalamnya, sepanjang data fisik dan data yuridis tersebut sesuai dengan data yang ada dalam surat ukur dan buku tanah hak yang bersangkutan. Sertipikat merupakan tanda bukti hak, yang berlaku sebagai alat pembuktian yang kuat. Alat pembuktian yang kuat' berarti, bahwa daftar-daftar buku tanah tidak merupakan satu-satunya alat pembuktian, sehingga pemegang hak yang sebenarnya masih dapat menggugat hak terhadap orang yang terdaftar sebagai pemegang hak dengan mengemukakan bukti-bukti lain. (Pasal 4 ayat (1), Pasal 29 ayat (10, ayat (2) dan ayat (3), Pasal 30 ayat (1), Pasal 31 ayat (1), dan Pasal 32 ayat (1) Peraturan Pemerintah Nomor 24 Tahun 1997, tentang Pendaftaran Tanah.

${ }_{14}$ Pasal 33 ayat (1) Peraturan Pemerintah Nomor 24 Tahun 1997 tentang Pendaftaran Tanah. 
Dalam penyelenggaraan pendaftaran tanah untuk pertama kali menurut Peraturan Pemerintah Nomor 10 Tahun 1961, secara tegas dibedakan antara penyelenggaraan pendaftaran tanah secara lengkap (sistematik) dan pendaftaran tanah tidak lengkap (secara sporadik), dan dalam Peraturan Pemerintah Nomor 24 Tahun 1997 tidak dibedakan lagi antara Sertipikat dan Sertipikat Sementara dan antara Surat Ukur dan Gambar Situasi. ${ }^{15}$

Menurut Peraturan Pemerintah Nomor 24 tahun 1997 baik pendaftaran tanah secara sporadik maupun pendaftaran tanah secara sistimatis terhadap pengukuran bidang-bidang tanahnya diterbitkan Surat Ukur tidak ada istilah lagi Gambar Situasi.

Pengukuran bidang tanah baik sporadik maupun sistematik harus tetap memenuhi kaidah-kaidah teknis pengukuran dan pemetaan sehingga bidang tanah yang diukur dapat dipetakan dan dapat diketahui letak dan batasnya di atas peta serta dapat direkonstruksi batas-batasnya di lapangan.

Pendaftaran tanah secara sporadik meliputi bidang-bidang tanah atas permintaan pemegang atau penerima hak yang bersangkutan secara individual atau secara masal.

Pendaftaran tanah secara sistematik dibiayai dengan anggaran Pemerintah Pusat atau Daerah, atau secara swadaya oleh masyarakat dengan persetujuan Menteri Agraria. Dalam hal pendaftaran tanah secara sistematik Kepala Kantor Pertanahan dibantu oleh Panitia Ajudikasi yang dibentuk oleh Menteri atau Pejabat yang ditunjuk.

Dalam Pasal 32 ayat (2) Peraturan Pernerintah Nomor 24 Tahun 1997 tentang pendaftaran tanah, mengatur sebagai berikut:

Dalam hal atas suatu bidang tanah sudah diterbitkan sertipikat secara sah atas nama orang atau badan hukum yang memperoleh tanah tersebut dengan itikad baik dan secara nyata menguasainya, maka pihak lain yang merasa mempunyai hak atas tanah itu tidak dapat lagi menuntut lagi pelaksanaan hak tersebut apabila dalam

\footnotetext{
15 Peraturan Pemerintah No. 24 Tahun 1997 tentang Pendaftaran Tanah
} 
waktu 5 (lima) tahun sejak diterbitkannya sertipikat itu tidak mengajukan keberatan secara tertulis kepada pemegang sertipikat dan Kepala Kantor Pertanahan yang bersangkutan ataupun tidak mengajukan gugatan ke Pengadilan mengenai penguasaan tanah atau penerbitan sertipikat tersebut. ${ }^{16}$

Memperhatikan isi ketentuan pasal tersebut, apabila dikaji secara mendalam, maka ketentuan pasal tersebut sebenarnya mengabaikan hak azasi manusia, dan mengakibatkan kematian perdata, sebab bertentangan dengan Pasal 3 Kitab Undang-Undang Hukum Perdata (KUHPer), menyatakan bahwa, Tiada suatu hukuman pun mengakibatkan kematian perdata, atau kehilangan segala hak kewarganegaraan. ${ }^{17}$ Karena di negara yang menganut sistem pendaftaran tanah positifpun tidak ada yang menghapus hak gugat atau hak keperdataan orang atau badan hukum, sehingga apabila yang bersangkutan dalam gugatannya dapat membuktikan sebagai pemilik sebenarnya akan diberi ganti rugi oleh pemerintah, ini seharusnya yang dimaksud dengan kepastian hukum.

Pasal tersebut juga dilandasi oleh lembaga rechtsverwerking dalam hukum adat, umumnya untuk tanah pertanian ladang berpindah yang banyak terjadi di luar Pulau Jawa dan Madura, jadi tidak dapat disamaratakan secara nasional. Pasal tersebut juga terlalu dini karena pemerintah belum siap dengan lembaga ganti rugi, dan berkesan menghapus pemberian ganti rugi. Diusulkan pasal tersebut dihapus atau diganti menjadi bunyi tulisan sebagai berikut:

Dalam hal seseorang atau badan hukum terdaftar pada buku tanah selama 20 (dua puluh) tahun tanpa ada gugatan atau selalu dapat dipertahankan haknya di Pengadilan dari gugatan pihak lain dan hak tersebut diperoleh secara sah atas nama orang atau badan hukum dengan itikad baik dan secara nyata menguasai bidang tanah atau satuan rumah susun yang bersangkutan, tidak dapat diganggu gugat. Pemilik sebenarnya yang berhak dan dapat dibuktikan haknya dengan Putusan Pengadilan dapat memperoleh ganti kerugian dari Pemerintah.

\footnotetext{
16 Pasal 32 ayat (2) Peraturan Pernerintah Nomor 24 Tahun 1997 tentang Pendaftaran Tanah

${ }^{17}$ Pasal 3 Kitab Undang-Undang Hukum Perdata (KUHPer)
} 
Asas rechtsverweking dalam hal ini dimaksudkan untuk menciptakan keseimbangan perlindungan hukum kepada pembeli yang beritikad baik dan pemilik sebenarnya, Waktu 20 (dua puluh) tahun dipandang cukup untuk melindungi mereka yang misaInya sedang menjalani hukuman, tugas belajar di luar negeri, pelarian politik yang memperoleh warisan. ${ }^{18}$

\subsection{Historis Singkat Tanah dan Bangunan Benteng Pendem Ngawi}

Dalam perang Diponegoro pada tahun 1825-1830 untuk melawan kolonial Belanda di Ngawi berkobar, yang dipimpin oleh Adipati Judo Diningrat dan Raden Tumenggung Suro Dirdjo bersama Wirotani, salah satu pengikut Pangeran Diponegoro, untuk daerah Madiun dalam memberontak kaum kolonial Belanda dipimpin oleh Bupati Kerto Dirdjo, dan untuk wilayah Ngawi yang berdekatan dengan Madiun, adalah tempat strategis di Jawa Timur sebagai Pusat Perdagangan dan Pelayaran melalui Sungai Bengawan Solo, yang menghubungkan Surabaya-Solo, maka Ngawi oleh Tentara Knil Belanda dijadikan Pusat Pertahanan Perang Belanda diwilayah Madiun, Ngawi pada saat Perang Diponegoro.

Pada tahun 1825 Ngawi berhasil direbut dan diduduki oleh Tentara Knil Belanda, maka untuk mempertahankan penguasaan wilayah Madiun-Ngawi, Tentara Knil Kolonial Belanda, membangun Benteng Pendem, yang sengaja dibuat lebih rendah dari tanah sekitar yang dikelilingi dengan urugan tanah lebih tinggi dari pada bangunan Benteng, untuk itu apabila terlihat dari Luar posisi bangunan Benteng Pendem, yang dulunya digunakan untuk Markas Pertahanan Tentara Knil Belanda, terlihat terpendam, dan konon cerita Rakyat Ngawi, awalnya disekitar Benteng ada kolom dan didalam kolam ada banyak Buaya, yang sengaja dipelihara oleh Tentara Knil Belanda.

\footnotetext{
${ }^{18}$ Pendapat Ini merupakan sumbang pendapat dari Kepala Kantor Pertanahan Kabupaten Jember (Ir. Tjahjo Arianto, SH., M. Hum) dengan suratnya yang ditujukan kepada Kepala Badan Pertanahan Nasional tanggal 14 Maret 2002 No. 200.353/4-719
} 
Benteng Pendem Ngawi terletak di Kelurahan Pelem Kecamatan Ngawi, Kabupaten Ngawi, lokasi mudah dijangkau, tepatnya dari Kantor Pemerintah Kabupaten Ngawi \pm 1,5 KM arah timur laut, berada di lokasi tanah disudut pertemuan Sungai Bengawan Solo dengan Sungai Madiun.

Benteng Pendem Ngawi dibangun oleh Kolonial Belanda selesai tahun 1845, pada saat Tentara Knil Belanda dipimpin oleh Van Den Bosch, dihuni \pm 250 Personil Tentara Belanda, Dengan Peralatan : semua Tentara Belanda dilengkapi dengan Senjata Bedil, 6 buah Meriam Api dan ditambah kekuatan 60 Personil Kaveleri Tentara Knil Belanda.

Kondisi saat ini bangunan Benteng Pendem Ngawi, yang berdiri diatas tanah $\pm 15 \mathrm{Ha}$, dengan luas bangunan Induk $165 \mathrm{M} 2 \times 80 \mathrm{M} 2$, dikelilingi Tembok setinggi $\pm 4 \mathrm{M}$, hanya ada satu pintu masuk dari arah barat menuju ke arah timur ke Bangunan Benteng Pendem, dan dijaga oleh Penjaga, diluar bangunan Benteng Pendem sudah ada bangunan Pariwisata yang dibangun oleh Pemerintah Daerah Kabupaten Ngawi. ${ }^{19}$

Dengan melestarikan cagar budaya, sangat cocok bagi para Pembaca Penelitian ini, untuk berkunjung di lokasi Benteng Pendem Ngawi, sebagai bentuk turut serta melihat dan melestarikan sejarah bangsa, sambil menikmati Pariwisata di Benteng Pendem Ngawi “ Benteng Van Den Bosch “ Peninggalan Tentara Knil Belanda.

\subsection{Keududukan Hukum Para Pihak dalam Sengketa Tanah dan Bangunan Benteng Pendem Ngawi-Ex Knil Belanda di Kabupaten Ngawi}

Dalam latar belakang masalah yang telah diuraikan di atas, maka diketahui bahwa TNI AD KODAM V/Brawijaya Cq Batalyon Armed Ngawi menguasai tanah dan bangunan Benteng Pendem Ngawi dengan hak okupasi yang diperoleh pada saat Negara dalam Keadaan Darurat Militer dengan bukti data dokumen sebagai berikut :

${ }^{19}$ Direktori Wisata, "Menelisik Wisata Heritage Benteng Pendem Van De Bosch di Ngawi, Jawa Timur "https://direktori-wisata.com/menelisik-wisata-heritage-benteng-pendem-van-debosch-di-ngawi-jawa-timur/, Akses 17 Februari 2019 
5.3.1. Surat dari Direktorat Genie AD Gi Bangunan ST V/16 Kediri tanggal 17 Maret 1956 tentang penjelasan Benteng Ngawi

5.3.2. Surat dari Komando Daerah Militer VIII Brawijaya Zeni Bangunan Korem 81 tanggal 5 Maret 1964 tentang Daftar tanah kosong/lapangan Milik Angkatan Darat dalam Daerah Zeni Bangunan Dam VIII / Sub 16 Seksi Madiun tahun 1963.

5.3.3. Gambar Situasi Peta tanah AD di Desa Pelem Kecamatan Ngawi Kabupaten Ngawi tanggal 12 Maret 1965

5.3.4. Surat dari Komando Daerah Militer VIII Brawijaya Zeni Bangunan Rayon 81 tanggal 2 Maret 1965 tentang Daftar Gedung Gedung milik Pemerintah/Partikelir (umum) yang dipergunakan untuk rumah tangga (RT) oleh $\mathrm{AD}$ dalam Daerah Zeni Bangunan Rayon 81 Madiun dalam tahun 1965.

5.3.5. Surat dari Komando Konstruksi Dam VIII Rayon Konstruksi 081 Madiun tanggal 30 Desember 1977 tentang Ruang Gambar Situasi tanah dan bangunan AD di Desa Pelem Ngawi.

5.3.6. Surat Keterangan dari Kepala Desa Pelem Kecamatan Ngawi Kabupaten Daerah Tingkat II Ngawi tanggal 20 Juni 1981 tentang tanah yang terletak di jalan Diponegoro Desa Pelem Ngawi sejak tahun 1950 dikuasi oleh Angkatan Darat.

Berdasarkan bukti-bukti dokumen surat-surat tersebut diatas, jelas bahwa TNI AD Kodam V/Brawijaya Cq Batalyon Armed Ngawi menduduki tanah dan bangunan Benteng Pendem Ngawi- Ex Knil Tentara Belanda lebih dulu dari pada Kementerian Hukum dan HAM Cq Lembaga Pemasyarakatn Ngawi (LP. Ngawi). 
Penguasaan TNI AD Kodam V/Brawijaya Cq Batalyon Armed Ngawi adalah sah menurut Perundang-undangan yang berlaku, karena diperoleh berdasarkan Darurat Militer, dan sekitar tahun 2015 tanah seluas $\pm 15.000 .000 \mathrm{M} 2$ (15 Ha), yang diokupasi TNI AD, telah terbit Sertipikat Hak Pakai atas nama Pemegang hak Pemerintah RI Cq Kementerian Pertahanan, sebagai aset Negara dalam Pengelolaan TNI AD Kodam V/Brawijaya.

Tanah dan Bangunan Benteng Pendem Ngawi telah terdaftar dalam Regestrasi Tanah IKN TNI AD Nomor : 30805002 Penggunaan terdahulu untuk Makoyon Armed 12/76 Para Ngawi Penggunaan sekarang untuk Asrama Prajurit dan Gudang Munisi serta untuk Latihan Militer Batalyon Armed 12/76 Ngawi.

Bupati Pemerintah Daerah Kabupaten Ngawi pernah mengirim Surat kepada Pangdam V/Brawijaya Nomor : 556/01.062/404.107/2011 tanggal 25 Oktober 2011 tentang Permohonan izin untuk perbaikan Benteng Van Den Bosch (Benteng Pendem) Kabupaten Ngawi, sebagai upaya Pemerintah Kabupaten Ngawi dan Pemerintah Pusat untuk menjaga kelestarian bangunan bersejarah Van Den Bosch (Benteng Pendem) aset TNI AD di Kabupaten Ngawi.

Untuk kedudukan hukum Pemerintah Daerah Kabupaten Ngawi, secara administrasi memang tidak memiliki dokumen data kepemilikan atas tanah dan Bangunan Benteng Pendem Ngawi yang didapat dari peninggalan Ex Knil Belanda, namun demikian Pemerintah Daerah Kabupaten Ngawi berwenang untuk melestarikan Peninggalan sejarah Purbakala sebagai Budaya bangsa yang harus diamankan dan dijunjung tinggi untuk penelitian pendidikan dan pengembangan ilmu pengetahuan dan dapat digunakan untuk lokasi Pariwisata.

Untuk itu Pemerintah Daerah Kabupaten Ngawi, dapat mengadakan kerja sama untuk pemanfaatan Aset Negara, dengan TNI AD Kodam V/Brawijaya, terhadap Tanah dan Bangunan Benteng Pendem Ngawi, sebagai Tempat Pariwisata, yang dapat menarik 
wisatawan lokal atau wisatawan asing, agar Pemerintah Daerah Kabupaten Ngawi dikenal dengan nama Kota Pariwisata. ${ }^{20}$

Terkait kedudukan Lembaga Pemasyarakatan Ngawi (LP Ngawi) dalam penguasaan tanah tersebut, Direktorat Djendral Pemasyarakatan (Departemen Kehakiman RI) pernah mengirim Surat kepada TNI AD Kodam V/Brawijaya Nomor : DP.5.4/7/2 tanggal 23 Juni 1971 tentang Persoalan tanah pertanian Benteng LP. Ngawi diantaranya menjelaskan bahwa megenai status tanah Pertanian Benteng, menurut catatan yang ada, sejak jaman Kolonial Belanda, oleh Dep.V.Oerlog telah diserahkan kepada Dep. V. Justitie dan sejak itu telah berpuluh puluh tahun lamanya dikuasai dan diawasi oleh LP. Ngawi.

Untuk itu Kementerian Hukum dan HAM Cq Lembaga Pemasyarakatan Ngawi (LP Ngawi), memang mempunyai dokumen data tanah dan bangunan Benteng Pendem Ngawi, dengan luas tanah $\pm 10 \mathrm{Ha}$, dan sekitar tahun 2015 telah Terbit Sertifikat Hak Pakai atas nama Pemegang hak Pemerintah Republik Indonesia Cq Kementerian Hukum dan HAM di Jakarta, penggunaan untuk Pelatihan Nara Pidana dari Lembaga Pemasyarakatan Ngawi (LP Ngawi), yang berwenang dalam bidang Pembinaan dan Pemulihan Masyarakat, maka dengan demikian LP Ngawi masih tetap menggunakan dan memelihara tanah dan bangunan Benteng Pendem Ngawi dan bahkan LP Ngawi telah mempunyai bangunan diatas tanah tersebut.

\section{Kesimpulan}

Berdasarkan penjelasan di atas, maka dapat disimpulkan bahwa kedudukan hukum TNI AD KODAM V/Brawijaya Cq Batalyon Armed Ngawi dalam penguasaan tanah dan bangunan banteng adalah sah hal tersebut didasarkan pada hak okupasi tanah dan bangunan Benteng Pendem Ngawi yang diperoleh pada saat Negara dalam Keadaan Darurat Militer dengan bukti

${ }^{20}$ Peraturan Menteri Keuangan No. 96/PMK.06/2007 tentang Tata Cara pelaksanaan penggunaan, pemanfaatan, penghapusan dan pemindah tanganan Barang Milik Negara. 
data diantaranya Surat dari Direktorat Genie AD Gi Bangunan ST V/16 Kediri tanggal 17 Maret 1956 tentang penjelasan Benteng Ngawi. Kemudian untuk kedudukan hukum Pemerintah Daerah Kabupaten Ngawi, secara Administrasi memang tidak memiliki dokumen data tanah dan Bangunan Benteng Pendem Ngawi, namun demikian Pemerintah Daerah Kabupaten Ngawi berwenang untuk melestarikan Peninggalan sejarah Purbakala sebagai Budaya bangsa yang harus diamankan dan dijunjung tinggi. Terkait kedudukan Lembaga Pemasyarakatan Ngawi (LP Ngawi) dalam penguasaan tanah tersebut, Direktorat Djendral Pemasyarakatan (Departemen Kehakiman RI) pernah mengirim Surat kepada TNI AD Kodam V/Brawijaya Nomor : DP.5.4/7/2 tanggal 23 Juni 1971 tentang Persoalan tanah pertanian Benteng LP. Ngawi diantaranya menjelaskan bahwa megenai status tanah Pertanian Benteng, menurut catatan yang ada sejak jaman Kolonial Belanda oleh Dep.V.Oerlog telah diserahkan kepada Dep. V. Justitie dan sejak itu telah berpuluh puluh tahun lamanya dikuasai dan diawasi oleh LP. Ngawi dan hal tersebut diperkuat dengan dokumen data tanah dan bangunan Benteng Pendem Ngawi dengan luas tanah $\pm 10 \mathrm{Ha}$, dan sekitar tahun 2015 telah Terbit Sertipikat Hak Pakai atas nama Pemegang hak Pemerintah Republik Indonesia Cq Kementerian Hukum dan HAM di Jakarta. 


\section{DAFTAR PUSTAKA}

\section{Buku}

Ade Saptomo. Pokok-Pokok Metodologi Penelitian Hukum. Surabaya: Unesa University Press, 2007.

Dianne Chappellle. Land Law. London: Pitman Publishing, 1997.

Michael G. Kitay. Land Acquistion in Deeveloping Countries, Policies and Procedures of the Public Sector. A Linclon Institute of Land Policy Book, 1983.

\section{Artikel Jurnal}

Dias Restu Wijayanti. Upaya Penyelesaian Sengketa Tanah Antara Masyarakat Dengan TNI (Studi Kasus Di Desa Setrojenar, Kecamatan Buluspesantren, Kabupaten Kebumen) Tahun 2015. FKIP, Universitas PGRI Yogyakarta, n.d.

Shidarta. "Peragaan Pola Penalaran Hukum Dalam Kajian Putusan Kasus Tanah Adat Kajian Putusan Nomor 22/PDT.G/2004/PN.AB.” JURNAL YUDISIAL 3, no. 3 (2010).

\section{Peraturan Perundang-undnagan}

Peraturan Pemerintah Nomor 24 Tahun 1997 tentang Pendaftaran Tanah

Kitab Undang-Undang Hukum Perdata (KUHPer)

Peraturan Menteri Keuangan No. 96/PMK.06/2007 tentang Tata Cara pelaksanaan penggunaan, pemanfaatan, penghapusan dan pemindah tanganan Barang Milik Negara.

\section{Hasil Wawancara dan Observasi}

Wawancara dengan Ir. Tjahjo Arianto, SH., M. Hum Kepala Kantor Pertanahan Kabupaten Jember tanggal 14 Maret 2002.

\section{Media Online}

Direktori Wisata, "Menelisik Wisata Heritage Benteng Pendem Van De Bosch di Ngawi, Jawa Timur "https://direktori-wisata.com/menelisik-wisataheritage-benteng-pendem-van-de-bosch-di-ngawi-jawa-timur/, Akses 17 Februari 2019 